\title{
The role of the creolized text in Dave Barry's comic idiodiscourse
}

\author{
O. V. Kuznietsova
}

\author{
V.N. Karazin Kharkiv National University \\ Corresponding author. E-mail: olgakuz3007@gmail.com
}

\begin{abstract}
Paper received 26.10.17; Revised 29.10.17; Accepted for publication 30.10.17.
https://doi.org/10.31174/SEND-PH2017-145V41-04
\end{abstract}

Abstract: The article substantiates basic postulates of idiodiscourse as specific self-expression of the author. The paper explores comic idiodiscourse of a modern American writer Dave Barry which is explicated by a combination of verbal and non-verbal elements. The au-thor's creative manifestation is shown up in particularities of chapter structures, front covers, as well as linguistic tools common for D. Bar-ry's idiodiscourse being his "visiting card".

Keywords: comic idiodiscourse, creativity, creolization, creolized text, front cover, idiodiscourse.

Introduction. Linguistics of the XXI ${ }^{\text {st }}$ century is primarily focused on research that study mechanisms of verbalization of human knowledge about the surrounding world, and, on the other hand, - communication of information transfer. For this reason "among strong arguments of modern linguistics are anthropocentrism, functionalism and explanatoriness" [5, c. 5]. Activity of these features defines idiodiscursive studies as one of the most currently important issues among modern researchers.

A creolized text has been an object of study in media discourse by (E.E. Anisimova, I.L. Biluk, D.P. Chigaev, N.S. Gromova) and political discourse (M.B. Voroshylova, A.A. Kozakov). For the first time a creolized text is studied in comic idiodiscourse especially when it is represented on front covers as a method of creating comic effect. Thus, there is much concern about comic text comprehension in modern society. Its content induces the addressee to mental activity - the most active process of creative thinking but not only the perception of ready-made non-reflective understanding. Thereby, the aim of the research is to review Dave Barry's comic idiodiscourse specificity, verbal and non-verbal tech-niques that lead to humorous effect.

Methods and Materials. The study is based on a range of complementary methods on account of the necessity to fully study comic idiodiscourse as a text-discursive formation. Dis course-typological analysis is used when features of comic idiodiscourse are discovered. The next applied method is text-interpretation analys is that is used while defining the presence of a humorous effect in Dave Barry's idiodiscourse. Intent analys is is subjected to the aim to disclose intentions of the author, who resorts to humorous communication. The following comic literary texts by the modern American writer-humorist Dave Barry are chosen: "Dave Barry is Not Making This Up", "Dave Barry's Homes and Other Black Holes", "Dave Barry Talks Back".

Results and Discussion. Intellectual cognition of reality is realized in the language of a creative personality, in particular, a personality of the writer, his idiodis course. According to V.O. Samokhina, idiodiscourse is a specific, carefully thought out and realized self-expression of the author, that forms his character, recognition, style in certain terms of communication, both general and specific characteristics; text as a verbal component of verbal or writing communication; communicative situation in which the author pursues, mainly, aes thetic aims, and a writer-humorist - besides, also the aim to make laugh, to amuse [6, p. 89-90].

This definition may be expanded in the following way, idiodiscourse is the author's personal individual method of organization of his own knowledge, ideas or experience, that he uses in language (orally or in writing) that functions as a mediator between him and his audience. Idiodiscourse is the standard of verbal and non-verbal behavior of a creative language personality in communicative space taking into account extralinguistic factors; creative display of the author's reflection, that exists in totality of thematically close texts affected by the author's individual vision of the world picture, his linguo-creative thinking, that can be found in key images, themes, set of expressive and graphic devices that make the "master hand" recognizable. We consider idiodis- course of a certain author to be expressed not only in artistic discourse but also in its other types, for example political, pedagogical, scientific, humorous etc., because in different discourses there are outstanding personalities that can be distinguished by the "author's handwriting", creative manner of written and verbal communication. Such display of the author's individuality and uniqueness "gives the individual an opportunity to approve himself as a personality who co $\mathrm{n}$ - ducts him/herself in dialogic co-operation passively or as a communicative leader, to express the features of the temper-ament, show a favour to [...] style of language communica-tion" [8, p. 136].

Dave Barry's creative potential finds explication in various humorous paradoxes that manifest his linguistic ingenuity in different extents of language system. Creativity helps the author to find something extraordinary to interest his readers. It is a phenomenon whereby something new and different is formed. Dave Barry as an example of a creative personality is characterized as: " a courageous individual, who tries new; intuition plus logic; great sense of humour, he is interested in the process itself but not in the result; fond of looking for something new; always in search of answers, knowledge, ideas. Comic writer - it is creativity, combined with intelligence: he who can consider a problem from different perspectives, see it in a paradoxical way. " [7, p. 88]. The author's creative "instinct" lies in his ironic attitude to reality, wit, sense of humour, ability to es timate events with a humorous undertone. The created item may be intangible (such as an idea, a scientific theory, a musical composition, or a joke) or a physicalobject (such as an invention, a piece of literary work, or a painting). Creativity, as the original ability, dis tinguis hes a particular author among others, makes his texts recognizable, forms his personal literal style - forms his idiodiscourse.

Our study deals with comic idiodiscourse. It is a discourse of carnival view of life dipped into the sphere of comic tonality and communication where one can point out humorous themes, expressed by verbal and non-verbal means that provoke a comic effect. It is also a capacity for fooling that 
can be unders tood as the author's pers onal creative method, his vision of reality. A comic writer choos es humorous style of communication, corres ponding comic genres, strategies and communication channel. This communication is carried out in humorous atmosphere with the aim to give hedonic treat both to his reader and to hims elf. Such communication is called "fascinative" after V.I. Karasik [4, p. 127]. It means that participants are fas cinated by the process of communication. In this interaction all types of comic are represented: humour, satire, sarcasm, irony, often self-irony.

The author of comic idiodiscourse sets two main purposes:

1. To provoke his addressee's interest and involve him into communication. So that, the latter "creates" idiodiscourse together with the author, takes part in it: either empathizes, either criticizes the author.

2. To amuse and entertain his addressee, that is to create a comic effect.

To implement the foregoing aims Dave Barry uses creolized texts as an instrument of creating a comic effect in his idiodis course. We understand a creolized text as "a complex text formation in which verbal and non-verbal elements organize one visual, structural, notional and functional unit" [1, p. 17]. It has several typical characteristics: a complex form; a combination of different semiotic systems (two or more); in terms of interrelation, complementarity [3, p. 166]. Verbal information, as a rule, exerts rational influence and non-verbal activates unconscious (emotional) level of perception; verbal means give information about outside world while non-verbal - about emotional aspect of communication [ref. to 2].

Creolized texts in Dave Barry's idiodiscourse have two main ways of manifestation: in chapter structures and on front covers. A creolized text is viewed as a linguovisual phenomenon that consists of two non-homogeneous parts: verbal (text) and non-verbal (picture). The presence of these two key elements in Dave Barry's comic idiodiscourse has the meaning of interrelation as they exist jointly and form visual, structural and functional unity that affects the addressee. Their interaction leads to a creation of comic effect. This peculiarity characterizes Dave Barry as a humorous writer whose creative language is rendered by competence, inventiveness of comic themes in American communicative space [9, p. 73-74].

A creolized text as a medium of chapter organization is viewed according to two principles:

1. A non-verbal part includes a verbal one;

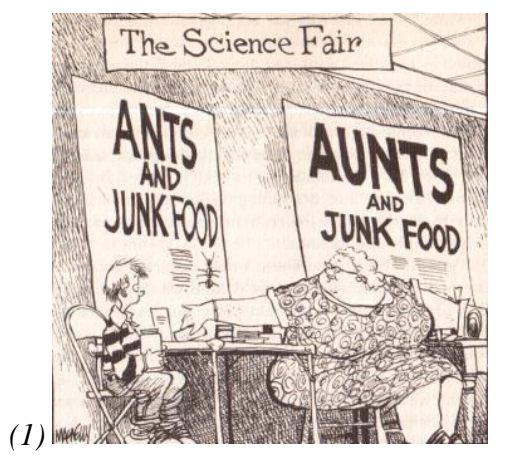

[Dave Barry is Not Making This Up, p. 3].

In the example above humour lies in the use of such device as agnomination: a semantic connection is established with consonant but different in meaning nouns "ant" and "aunt". It means that a student has conducted the experiment not only on ants but also on his aunt.

2. A non-verbal part and a verbal part are presented separately;

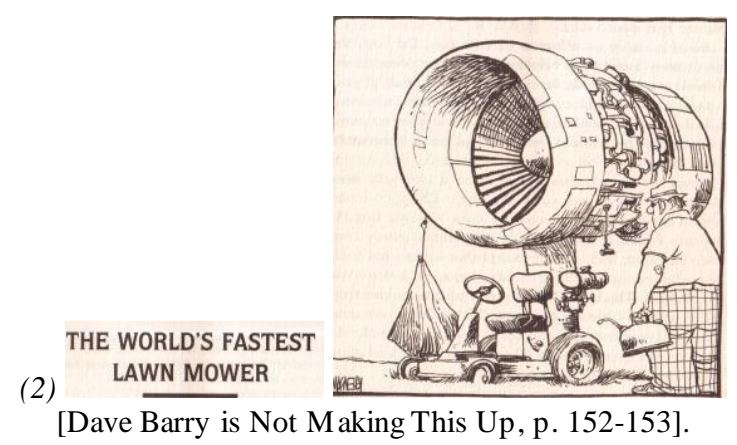

The conic effect of this example consists in usage of a hyperbole. According to the title of the chapter "The World's Fastest Lawn Mower", the reader starts to visualize it as a new-fangled device with lots of modern doo-dads, and instead of this, his/her expectations are even exaggerated as the designer has added an aircraft engine to it. Here arises a logical question: Where did he get it? Is it possible for an ordinary person to find such a detail?

Another characteristic element of Dave Barry's idiodiscourse is creolized front covers that are organized in a particular, creative way. On the front cover creolization is used intensively. It contains a non-verbal part - a photo, and a verbal part with the following key elements:

1. a title of the book (includes Dave Barry's name which reflects his autobiographical nature in a humorous way and manifes ts comic self-representation of his personal life experience);

2. subtitles (give additional information to the title);

3. a review to the book (outlines its humorous focus);

4. names of other books (show variety of author's works);

5. emphasizing phrase (accentuates the author's popularity).



The front cover contains: Dave Barry's photo; an emphasizing phrase that confirms the author's popularity "The Pulitzer Prize - winning humorist"; names of the books by Dave Barry "Dave Barry's Only Travel Guide You'll Ever Need and Dave Barry Talks Back".

A combination of the title of the book and the picture provokes a humorous effect through a stylistic device - metaphor. Comparis on of a typical house (that means not only a physical structure where you live but a special place - home - where you feel most comfortable and that belongs to you) with a "black hole" (something that constantly uses up a large amount of money without producing a good result). So, he compares a process of building a house with something awful that absorbs money and time like an abyss. 
(4)

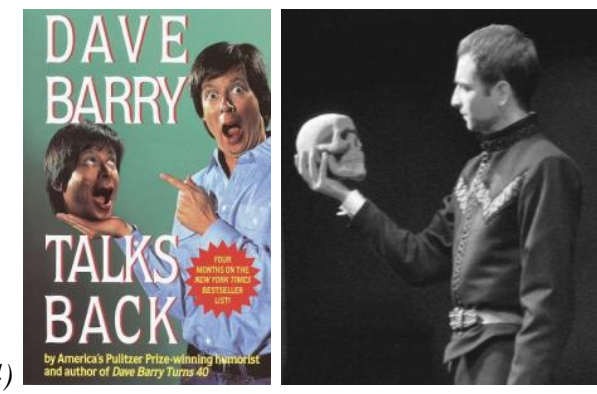

On this book cover a comic effect is reached through a stylistic device - allusion. Dave Barry resembles a theatre actor from the play "The Tragedy of Hamlet, Prince of Denmark" by William Shakespeare where the main character recites his monologue with a scalp in his hand, starting with the words "To be, or not to be: that is the question..."
But unlike Hamlet, who is depicted as a very thoughtful and concentrated man, Dave Barry looks astonished. As the phrase "to talk back" (a part of a title) means to "reply defiantly" we understand that his alter ego argues with him. So, on the book cover we can see a vivid dialogue instead of a reflective monologue.

Conclusions. Creolization in Dave Barry's comic idiodiscourse presents a unique pattern of humorous tonality which distinguishes his books fromother ones by the author's willingness to experiment and talented manipulation of various semiotic systems. Creolized texts serve as a "visiting card" of his talent and stir the reader to picture Dave Barry as a very creative pers onality-humorist. A combination of verbal and non-verbal components presents him as a person with a good sense of humour and a master of his craft.

\section{ЛІТЕРАТУРА}

1. Анисимова Е.Е. Лингвистика текста и межкультурная комму никация (на материале креолизованных текстов) / Е.Е. Анисимова .- М. : Академия, 2003 . - 128 с.

2. Бойко М.А. Функциональный анализ средств создания образа страны (на материале немецких политических креолизованных текстов) : автореф. дис. ... канд. филол. наук : 10.02.04 - Германские языки / Бойко М.А. - Воронеж, 2006. $-23 \mathrm{c}$.

3. Ворошилова М.Б. Политический креолизованный текст: ключи к прочтению : моногр. / М. Б. Ворошилова; Урал. гос. пед. ун-т. - Екатеринбург, 2013. - 194 с.

4. Карасик В.И. Языковое проявление личности / В.И. Карасик. - М.: Гнозис: 2015. -384 с.

5. Кубрякова Е.С. Язык и знания / Е.С. Кубрякова. - М. : Языки славянской культуры, 2004. - 560 с.

6. Самохина В.А. Карнавальная рефлексия в комическом идиодискурсе/ В.А. Самохина // Художні феномени в історії сві-

тової літератури: перехід мови в письменництво («Екоцентризм: культура і пр ир ода»): Тези доповідей ІІІ М іжнародної нау кової конференції. - Х. : ХНУ імені В. Н. Каразіна, 2017. - C. 89-91.

7. Самохина В.А. Креативная личность Linguisticus-шутника, или ученые-лингвисты смеются / В.А. Самохина // Когниция, комму никация, диску рс. - Х. : ХНУ імені В. Н. Каразіна, 2016. - №12. - С. 84-97.

8. Сусов И.П. Грамматика говорящего/И.П. Сусов // Акту альные проблемы коммуникативной грамматики; Тульск. гос. пед. ун-т. - Тула, 2000. - С. 130-138.

9. Kuznietsova O. Creolized book cover as an element of Dave Barry's comic idiodiscourse / O. Kuznietsova // 8th Łódź Symposium New Developments in Linguistic Pragmatics. Book of Abstracts/Edited by Piotr Cap. - University of Łódź, Poland, 2017. - P 73-74.

\section{ДЖЕРЕЛА ІЛЮСТРАТИВНОГО МАТЕРІАЛУ}

1. Barry D. Dave Barry is Not Making This Up / Barry D. - N.Y.: Ballantine Book, 1994. - 244 p.

\section{REFERENCES}

1. Anisimova E.E. Text linguistics and cross-cultural communication (a case study of creolized texts) / E.E. Anisimova . - M.: Academy, $2003 .-128 \mathrm{p}$.

2. Boyko M.A. Functional analy sis of devices that create country image (a case study ofl German political creolized texts) : synopsis of a thesis ... Cand. Sc.: 10.02.04- Germanic languages / Boyko M.A. -Voronezh, 2006. - 23 p.

3. Voroshilova M.B. Political creolized text: key s to reading: monograph / M.B. Voroshilova; Ural state pedagogical university. Ekaterinburg, 2013. - 194 p.

4. Karasik V.I. Language display of the personality / V.I. Karasik. - M.: Gnozis: 2015. - 384 p.

5. Kubry akova E.S. Language and knowledge / E.S. Kubry akova. M. : Languages of the Slavic culture, 2004. $-560 \mathrm{p}$.

6. Samokhina V.A. Carnival reflection in comic idiodiscourse/V.A. Samokhina/ Artistic phenomena in history of world literature :

language transition to writing ("Ecocentrism: culture and nature") : Abstracts of the $3^{\text {rd }}$ International scientific conference. - Kh. : V.N. Karazin Kharkiv National University, 2017. - P. 89-91.

7. Samokhina V.A. Creative personality of Linguisticus-joker, or scientists-linguists laugh / V.A. Samokhina // Cognition, communication, discourse. - Kh. : V.N. Karazin Kharkiv National University, 2016. - №12. - P. 84-97.

8. Susov I.P. Grammar of the speaker / I.P. Susov // Topical issues of communicative grammar; Tula State Pedagogical University Tula, 2000. - P. 130-138.

9. Kuznietsova O. Creolized book cover as an element of Dave Barry's comic idiodiscourse /O. Kuznietsova // 8th Łódź Symposium New Developments in Linguistic Pragmatics. Book of Abstracts/Edited by Piotr Cap. - University of Łódź, Poland, 2017. - P 73-74.

\section{Роль креолизованного текста в комическом идиодискурсе Дейва Барри}

\section{О. В. Кузнецова}

Аннотация. В статье обосновываются основные постулаты идиодискурса как особого способа самовыражение автора. В работе исследуется комический идиодискурс современного американского писателя Дейва Барри, который представлен комбинацией вербальных и невер бальныхэлементов. Креативное пр оявление автора отображается в своеобразных структурах глав, передних сторонах обложек, также как и в лингвистических приемах, свойственных для идиодискурса Д. Барри, которые являются его "визитной карточкой".

Ключевые слова: идиодискурс, комическийидиодискурс, креативность, креолизаиия, креолизованньй текст, передняя сторона обложки. 